\title{
Experimental hepatic cirrhosis in dogs caused by chronic massive iron overload ${ }^{1}$
}

\author{
PEDRO EURICO LISBOA
}

From the Clinica Universitaria de Patologia Medica, University Hospital of Santa Maria, Lisbon, Portugal

SUMmARY Starting in October 1966, 19 dogs have been subjected to massive parenteral iron loading using intravenous iron-dextran and intramuscular iron-sorbitol. Although 13 animals died, in many cases the deaths were attributable to fighting. The large doses of iron employed (up to $5.8 \mathrm{~g} / \mathrm{kg}$ ) were well tolerated by the surviving animals, and after 35 to 47 months five of the six survivors have developed hepatic cirrhosis with massive siderosis; the dog which has not yet developed cirrhosis received the smallest iron load. The liver pathology in many ways resembles that of human haemochromatosis, and may provide an experimental model for the study of chronic iron-induced liver injury.

Attempts to reproduce the hepatic lesion of human haemochromatosis by parenteral iron loading in experimental animals have repeatedly failed. An impasse seemed to have been reached when Brown and his associates were unable to find evidence of cirrhosis in dogs given iron loads of 0.5 to $1.0 \mathrm{~g} / \mathrm{kg}$ body weight despite periods of observation of up to seven years (Brown, Dubach, Smith, Reynefarje, and Moore, 1957). With continued iron administration, gradually increasing the total dose to 2.5 to $3.3 \mathrm{~g} / \mathrm{kg}$, all the animals died; although the exact cause of death was not established, necropsies showed no evidence of cirrhosis (Brown, Smith, Dubach, and Moore, 1959). It thus appeared that any hope of obtaining an experimental model of chronic ironinduced liver cirrhosis depended on conducting a study of impracticable length (possibly exceeding the normal life span of the animal) with a negative outcome as a possible prospect. Shortening the experiment by increasing the iron load was lethal at a prefibrotic stage.

The introduction of less toxic iron preparations and new routes of administration prompted a further long-term experiment of chronic massive iron overload in dogs and rabbits using intravenous irondextran and intramuscular iron-sorbitol. Starting in October, 1966, 19 dogs have been studied to date; six are still alive and five have developed cirrhosis.

Received for publication 11 March 1971.

${ }^{1}$ A preliminary report of this study was presented at the fifth meeting of tbe European Association for the Study of the Liver in Berne in September 1970.
This paper is a preliminary report of the study and deals mainly with the findings in the six surviving animals.

\section{Methods}

Nineteen mongrel dogs, mean $( \pm$ SEM) weight $8.7 \pm 0.9 \mathrm{~kg}$, have been studied during and after iron loading with iron-dextran (Imferon) and ironsorbitol (Jectofer). The dogs may be divided into groups according to the dose and type of iron preparation administered (Table 1).

Preliminary investigations in dogs $1-15$ included measurements of plasma glucose, urea, albumin, and globulin; serum iron, total iron-binding capacity, bilirubin, SGOT, and SGPT; peripheral blood count and examination of iliac crest marrow. In five dogs ferrokinetic studies were performed after intravenous injection of a tracer dose of radioiron. All these investigations were normal. Dogs 1-15 were submitted to laparotomy under sodium pentobarbitone anaesthesia for liver and skin biopsy and intraabdominal exploration. Hepatic histology before iron loading was normal in every case.

The animals were given the usual omnivorous dog diet of the department, consisting of varied foodstuffs including adequate meat. The folate content of the diet was not calculated but can be assumed to be adequate. Initially they were housed together in a single room but fighting between the overcrowded animals resulted in many deaths. After 18 months the six survivors were rehoused in individual cages. Since 1968 four liver biopsies have been performed 


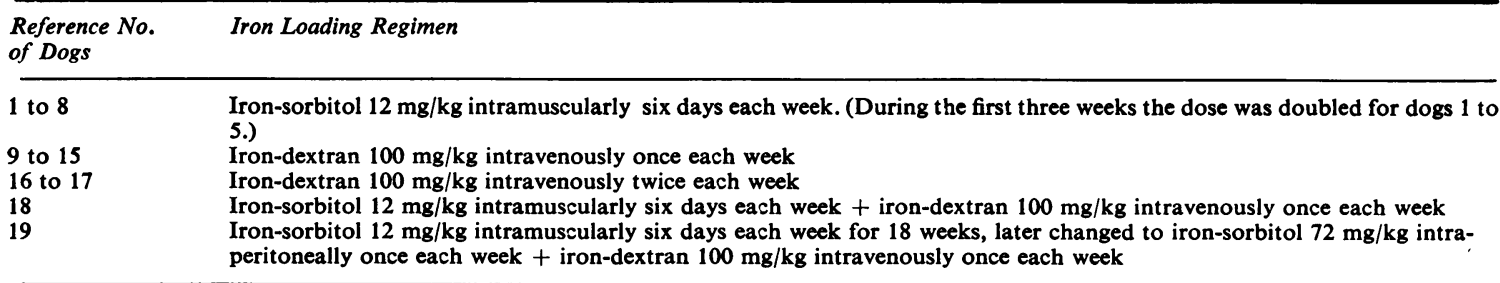

Table I Iron loading regimens employed

in each of these animals. Biochemical investigations (Table III) were performed at irregular intervals.

\section{Results}

Thirteen of the 19 animals died during the study. In 11 cases death probably resulted from fights. Dogs 1 and 2, given higher doses of iron-sorbitol, died early in the experiment (on the 21st and 26th day respectively), probably from acute iron toxicity. The ironloading regimen was consequently reduced by half. Others may have died from the same cause as it was not always easy to determine whether wounds had been inflicted before or after death. Necropsy examination was performed in all the dead animals and showed no other cause of death. These dogs are not considered further in the present paper.

The details of the six surviving animals are shown in Table II. In those given iron-sorbitol the total load has been calculated as $70 \%$ of the administered dose since $25-30 \%$ of this complex is of sufficiently small molecular size to be excreted in the urine (D'Amato, 1965; Lundin, 1965). These dogs have now survived for 35 to 47 months, and five of the six have developed cirrhosis. Dog 19, which has not yet developed cirrhosis, was the last to start iron loading and received a smaller dose than the others.

In all five dogs with cirrhosis the liver became markedly enlarged and granular (Figs. 1 and 2). A superficial collateral circulation developed (Fig. 3) making laparotomy more difficult. Liver histology showed disorganization of lobular architecture, with nodular regeneration, slight fibrosis, and mild inconstant mononuclear infiltration (Figs. 4-6). Massive deposits of iron were found in the parenchyma (Fig. 7) though siderosis was almost absent in the newly regenerated cells of pseudo-lobules. Findings in the animals dying early indicated that parenchymal siderosis was present from the very early stages of iron loading. Dog 19 has not yet developed cirrhosis but shows enlarged portal tracts.

Most of the animals tolerated the massive doses of iron well. Generalized pinkish pigmentation developed during the period of iron administration but later faded. The abdomen was enlarged due to enormous livers in all the dogs. Ascites was observed in one case only. Blindness did not develop, and repeated ophthalmoscopic examination was normal

\begin{tabular}{|c|c|c|c|c|c|c|}
\hline $\begin{array}{l}\text { Reference No. } \\
\text { of Dog }\end{array}$ & Mean Weight $(\mathrm{kg})$ & $\begin{array}{l}\text { Type of Iron and Route } \\
\text { of Administration }\end{array}$ & Total Dose $(\mathrm{g} / \mathrm{kg})$ & $\begin{array}{l}\text { Administration of } \\
\text { Total Dose (months) }\end{array}$ & $\begin{array}{l}\text { Duration of } \\
\text { Survival (months) }\end{array}$ & Cirrhosis \\
\hline Dog 5 & 11 & $\begin{array}{l}\text { Iron sorbitol } \\
\text { Intramuscular }\end{array}$ & 3.7 & $21 \cdot 7$ & 47 & + \\
\hline Dog 8 & 7 & $\begin{array}{l}\text { Iron sorbitol } \\
\text { Intramuscular }\end{array}$ & 3.5 & $13 \cdot 1$ & $39 \cdot 3$ & + \\
\hline $\operatorname{Dog} 9$ & 6 & $\begin{array}{l}\text { Iron dextran } \\
\text { Intravenous }\end{array}$ & 5 & $14 \cdot 2$ & 47 & + \\
\hline Dog 17 & $3 \cdot 5$ & $\begin{array}{l}\text { Iron dextran } \\
\text { Intravenous }\end{array}$ & 4.9 & $5 \cdot 3$ & 47 & + \\
\hline Dog 18 & $13 \cdot 5$ & $\begin{array}{l}\text { Iron dextran } \\
\text { Intravenous } \\
+ \\
\text { Iron sorbitol } \\
\text { Intramuscular }\end{array}$ & $5 \cdot 8$ & 10 & $36 \cdot 3$ & + \\
\hline Dog 19 & 22 & $\begin{array}{l}\text { Iron dextran } \\
\text { Intravenous } \\
+ \\
\text { Iron sorbitol } \\
\text { Intramuscular and } \\
\text { intraperitoneal }\end{array}$ & $1 \cdot 3$ & $12 \cdot 2$ & $35 \cdot 3$ & - \\
\hline
\end{tabular}

Table II Chronic iron overload in dogs

${ }^{1}$ In the case of iron sorbitol corrected to $70 \%$ to allow for renal excretion. 


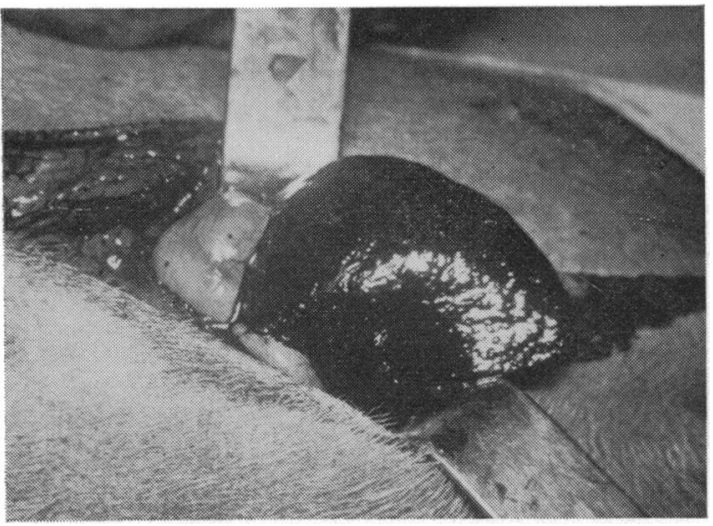

Fig. 1 Dog 18, October 1969. Diffusely granular liver surface.

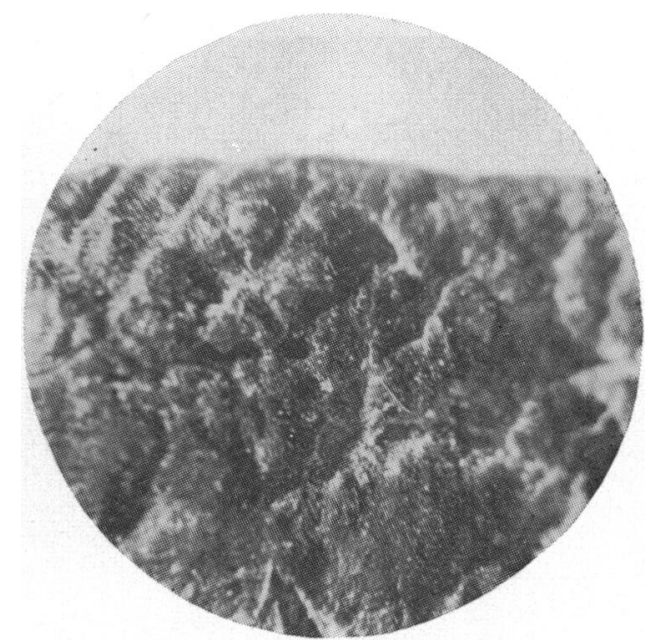

Fig. 2 Dog 18, October 1969. Wedge liver biopsy showing finely granular capsular surface at higher magnification than in Figure 1.

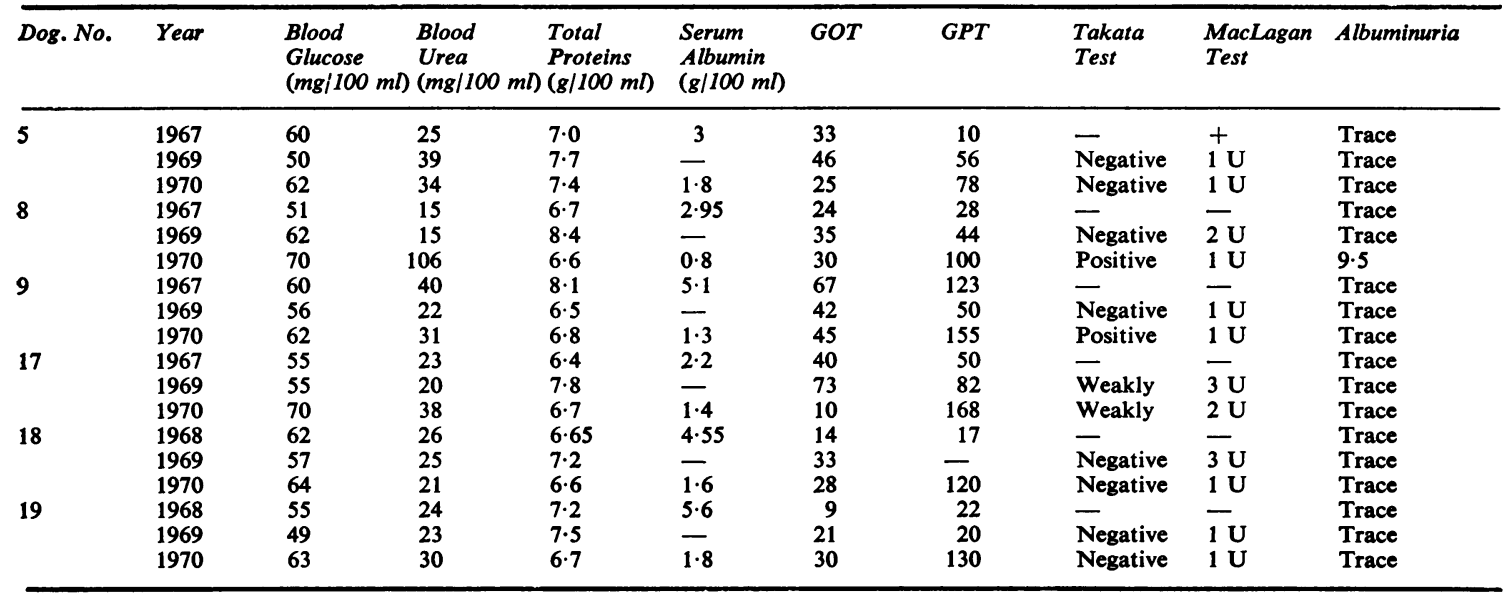

Table III Biochemical data in the surviving animals

without evidence of retinitis pigmentosa. There have been no signs of diabetes.

Apart from hyperferraemia, repeated laboratory tests failed to reveal any consistent biochemical abnormality during the first two years (Table III). Subsequently, however, the serum albumin level fell in most of the dogs and the SGPT levels rose. The very low serum albumin level in dog 8 may be partly due to heavy albuminuria devloping after 35 months; as the blood urea rose at the same time these changes may reflect the known nephrotoxic effect of iron-sorbitol. Dog 5 received iron-sorbitol in slightly higher total dosage without showing evidence of renal damage but the rate of iron loading was much slower (Table II).

\section{Discussion}

The liver injury produced by massive iron loading in these dogs resembles that of human haemochromatosis in the sequence of heavy siderosis, followed by portal fibrosis and cirrhosis, with only slight inflammation. However, for various reasons, caution is necessary in extrapolating these findings to the human disease. 


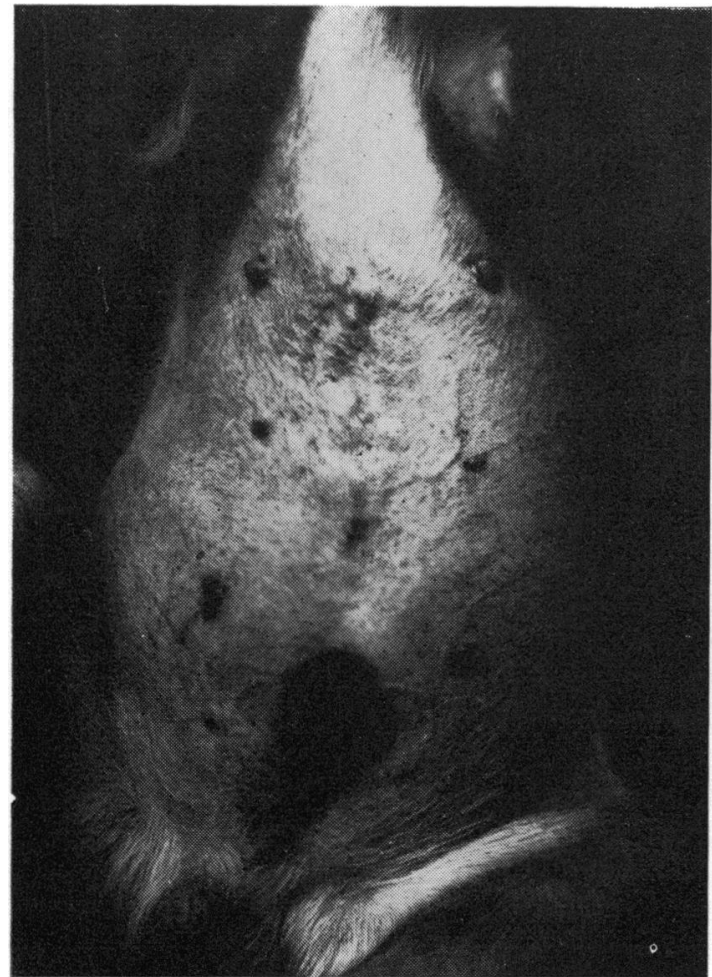

Fig. 3 Dog 9, September 1970. Distended subcutaneous abdominal wall veins.

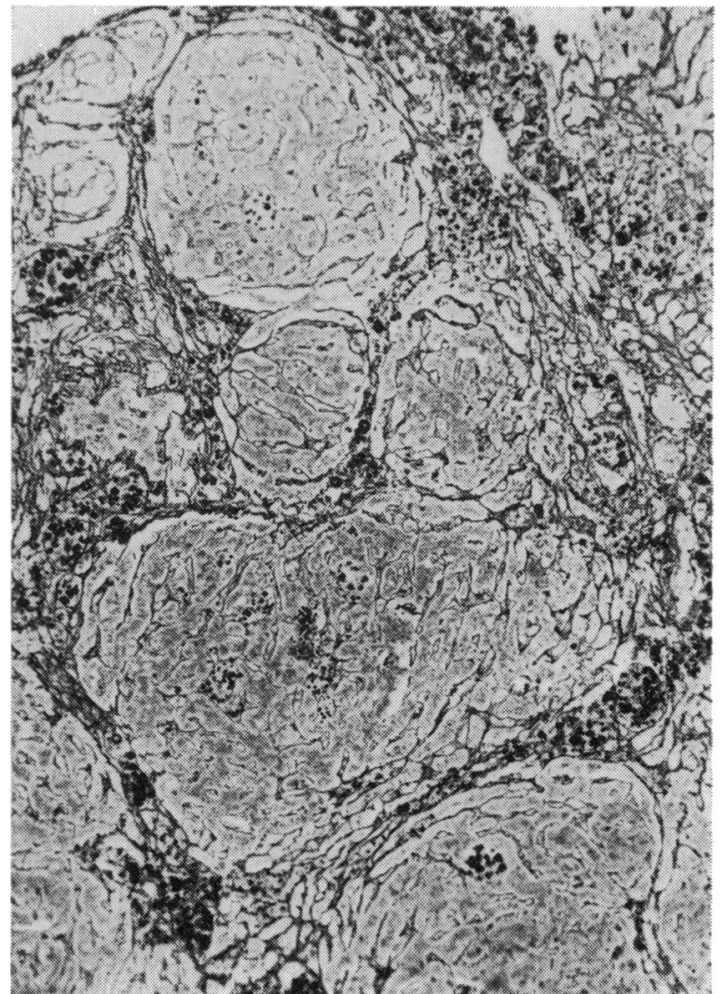

Fig. 4 Dog 5, iron load $3.7 \mathrm{~g} / \mathrm{kg}$, duration 23 months. Wedge biopsy specimen of liver showing nodular cirrhosis. Stain reticulin (Gordon and Sweet) $\times 72$.

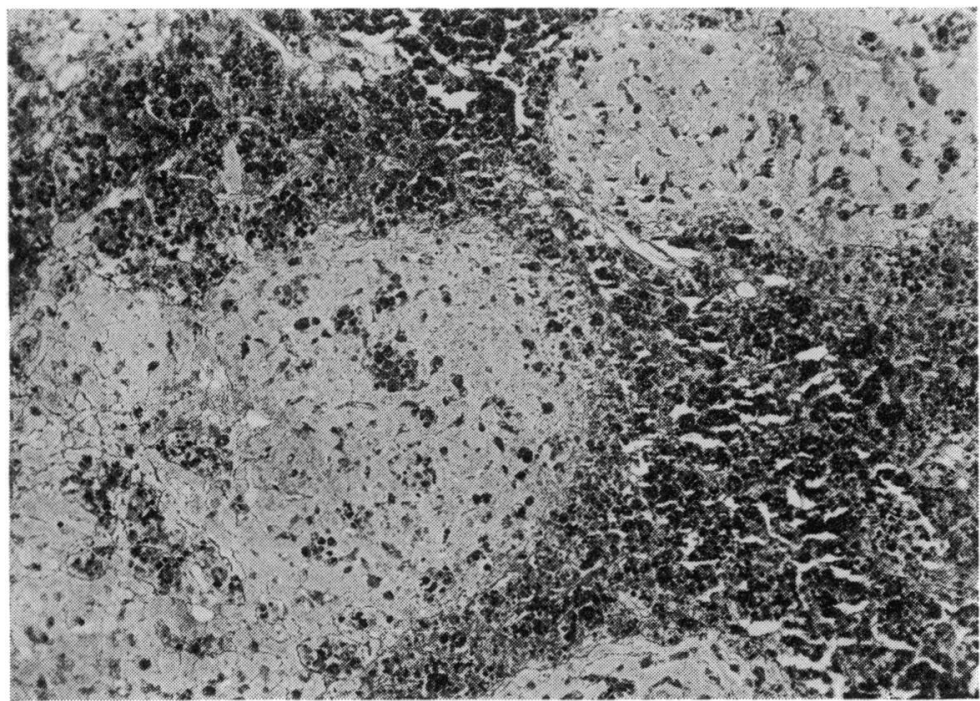

Fig. 5 Dog 9, iron load $5 \mathrm{~g} / \mathrm{kg}$, duration 45 months. Wedge biopsy specimen of liver. Stain reticulin (Gordon and Sweet) $\times 72$. 


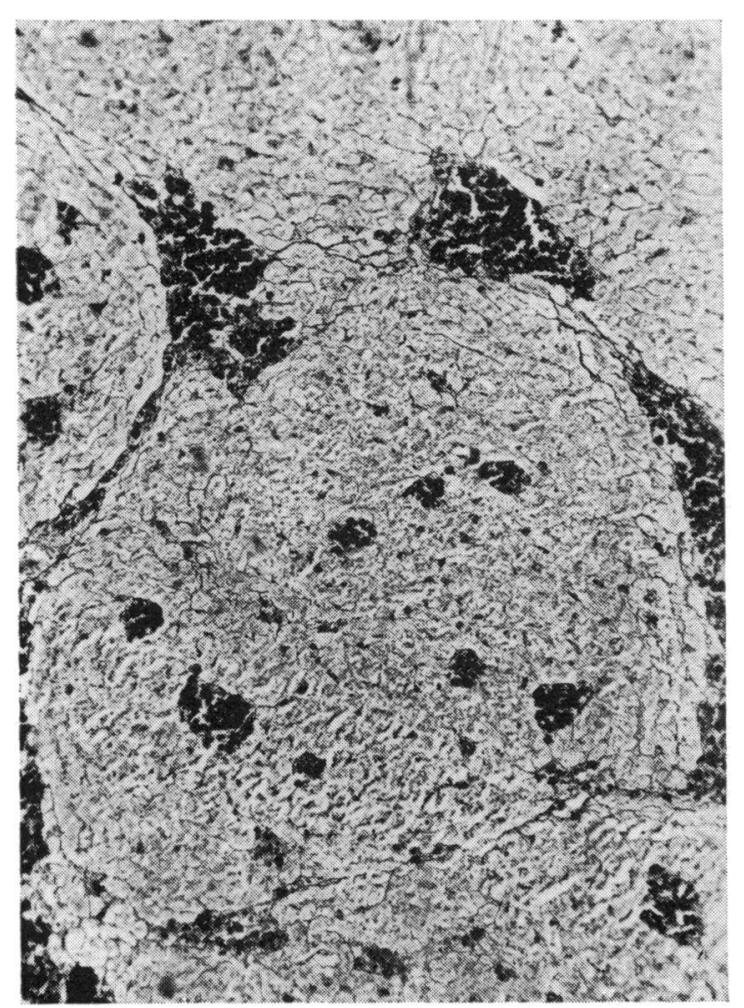

Fig. 6 Dog 18 , iron load $5 \cdot 8 \mathrm{~g} / \mathrm{kg}$, duration 54 months. Wedge biopsy specimen of liver. Stain reticulin (Gordon and $S$ weet $) \times 72$.

The total dose or iron given to the dogs was enormous compared with the quantities observed in human haemochromatosis. It is possible that the rapidity with which cirrhosis developed was in fact due to the large doses of iron employed. Cirrhosis has not yet developed in the dog receiving the smallest iron load.

The dogs were submitted to parenteral iron loading whereas idiopathic and secondary haemochromatosis in man results from increased intestinal absorption of iron. Pure parenteral iron overload in man only rarely leads to cirrhosis. However, human parenteral iron overload is usually due to multiple blood transfusions and not to non-haem complexes.

The reason for the success of the present study, when all previous attempts to produce experimental cirrhosis by chronic massive iron overload have failed, is uncertain. Early workers used iron loads that were small compared with those found in human haemochromatosis. Moreover, species differences with regard to fibrogenesis, inflammatory reactivity,

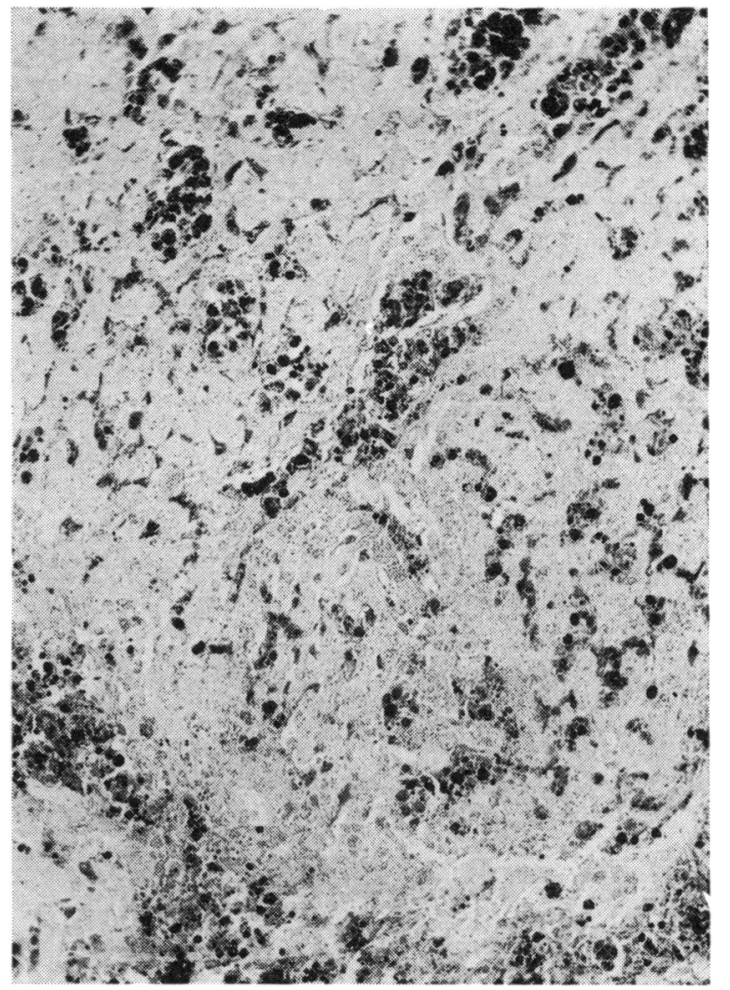

Fig. 7 Dog 9, iron load $5 \mathrm{~g} / \mathrm{kg}$, duration 23 months. Wedge biopsy specimen of liver showing parenchymal siderosis. Stain Perls $\times 160$.

and liver cell regeneration may act so as to impede the development of cirrhosis in rabbits and other laboratory rodents. These explanations, however, do not account for the difference in outcome between this study and those of Brown, Dubach, Smith, Reynefarge, and Moore (1957) and Brown, Smith, Dubach, and Moore (1959) who also used dogs. Contrary to their experience, most of the present animals tolerated the massive doses of iron well; ascites occurred in one dog only, and retinitis pigmentosa with blindness in none. Five out of the six animals received iron loads exceeding $3 \mathrm{~g} / \mathrm{kg}$ and yet remained alive for many months after the period of iron administration had ceased. The use of less toxic compounds, in larger doses and by more effective routes of administration, may have combined to achieve the results described here. If these findings are confirmed by others they may provide an experimental model for the study of a chronic, iron-induced liver injury in many ways resembling that of human haemochromatosis. 
I wish to thank specially Dr Amelia Baptista for the pathological studies on the liver biopsies. Gifts of Jectofer and of Imferon were made by Astra and Fisons respectively. The work was subsidized by a grant from the Fundaçăo Calouste Gulbenkian.

Reference:

Brown, E. B., Dubach, R., Smith, D. E., Reynafarje, C., and Moore,
C. V. (1957). Studies in iron transportation and metabolism. Long-term iron overload in dogs. J. lab. clin. Med., 50, 862-893.

Brown, E. B., Smith, D. E., Dubach, R., and Moore, C. V. (1959). Lethal iron overload in dogs. J. lab. clin. Med., 53, 591-606.

D'Amato, H. E. (1965). The pharmacology and general toxicology in animals. In Jectofer, Proceedings of a Conference, edited by H. E. D'Amato, pp. 19-23. AB Astra, Södertälje, Sweden.

Lundin, P. M. (1965). The effects on the kidney. In Jectofer, Proceedings of a Conference, edited by H. E. D'Amato, pp. 27-33. AB Astra, Södertălje, Sweden.

\section{The April 1971 Issue}

\section{THE APRIL 1971 ISSUE CONTAINS THE FOLLOWING PAPERS}

Peritoneoscopic features of intraabdominal vessels in cirrhosis of the liver G. P. JORI AND G. MAZZACCA

${ }^{75}$ Se-selenomethionine in the scintiscan diagnosis of primary hepatocellular carcinoma A. L. W. F. EDDleston, M. O. RAKe, A. P. PAGAltsos, S. B. OSBORN, AND ROGER WILLIAMS

Pacesetter potential of the human gastroduodenal junction H. L. DUTHIE, N. K. KWONG, B. H. BROWN, AND G. E. WHITTAKER

Effect of intragastric bile salts on ionic movement across normal human gastric mucosa after intravenous atropine $\mathrm{K}$. J. IVEY, L. DENBESTEN, AND J. A. CLIFTON

Effect of cycloheximide on intestinal secretion induced by hypertonic glucose C. H. HALSTED, D. I. GRAYER, E. H. LUEBBERS, J. H. YARDLEY, AND T. R. HENDRIX

Treatment of achalasia with pneumatic dilatations G. VANTRAPPEN, J. Hellemans, W. DELOOF, P. VALEMBOIS, AND J. VANDENBROUCKE

Dipeptidase deficiency and malabsorption of glycylglycine in disease states F. SADIKALI
An unusual case of self-induced electrolyte depletion D. R. LOVE, J. J. BROWN, R. FRASER, A. F. LEVER, J. I. S. ROBERTSON, G. C. TIMBURY, SHEENA THOMSON, AND M. TREE

Immunoglobulin-containing cells in the coeliac syndrome $\mathrm{K}$. W. PETTINGALE

Serum concentration of 19 serum proteins in Crohn's disease and ulcerative colitis B. WEEKE AND $\mathbf{s}$. JARNUM

Changes in the postoperative insulin test in relation to recurrent duodenal ulceration D. F. L. WATKIN AND H. L. DUTHIE

Immunofluorescent localization of enteroglucagon cells in the gastrointestinal tract of the dog JULIA M. POLAK, S. BLOOM, I. COULLING, AND A. G. E. PEARSE

The $\mathbf{G}$ cells in pernicious anaemia JULIA M. POLAK, I. COULlinG, W. DOE, AND A. G. E. PEARSE

Progress report Halothane hepatitis SHEILA SHERLOCK

Progress report Fibreendoscopy of the intestines M. CLASSEN

Notes and activities

Copies are still available and may be obtained from the PUBLISHING MANAGER, BRITISH MEDICAL ASSOCIATION, TAVISTOCK SQUARE, LONDON, WC1H 9JR, price $87 \frac{1}{2} \mathrm{p}$ 